\title{
ANALISIS PENGARUH INFLASI TERHADAP LAJU PERTUMBUHAN EKONOMI DI KOTA JAMBI
}

\author{
Prima Audia Daniel \\ STIE Muhammaadiyah Jambi
}

\begin{abstract}
In an economy of a country or region are certainly not apart from a problem that intertwined and mutually influence each other. These conditions always happen in all countries that there is in the world and not apart of this also on the Government of the city of Jambi. The economy of the city of Jambi who still has not shown the consistency of course is still influenced by other factors are interlinked, for instance variable inflation. Inflation is indeed directly does not affect economic growth however indirectly to provide disruption in spur economic growth. On the basis of things that writers do this research. the purpose of this research is; 1) analyzing the rate of growth of inflation and economic growth that occurred in the city of Jambi; 2) analyse the influence of inflation towards economic growth in the city of Jambi; 3) and see the relationship of inflation with economic growth in the city of Jambi. This research was conducted with the use of quantitative and qualitative approaches and utilizing secondary data becomes available. analytical tools used in this research is a simple linear regression and correlation of person who used to see the influence and relationship variables infalsi against economic growth. From the results of the discussion indicates that the inflassi effect negatively to economic growth and inflation have a negative relationship with economic growth. This means that rising inflation effect on the rate of economic growth in the city of Jambi.
\end{abstract}

Keywords: inflation, economic growth

\section{PENDAHULUAN}

Perubahan-perubahan pada berbagai sektor ekonomi tersebut akan mengakibatkan terjadinya pertumbuhan ekonomi, yang ditandai dengan naiknya produksi nasional, pendapatan nasional, dan pendapatan perkapita. Situasi semacam itu akan berlangsung secara terus-menerus. Pertumbuhan ekonomi dan pembangunan ekonomi merupakan dua istilah yang berbeda, sekalipun ada beberapa ahli mengatakan sama. Pertumbuhan ekonomi merupakan salah satu indikator dari keberhasilan pembanguanan ekonomi. Jadi akan ada pertumbuhan ekonomi jika ada pembangunan ekonomi dimana pembangunan ekonomi itu mengakibatkan perubahan-perubahan pada sektor ekonomi. Pendirian industriindustri baru dan meningkatnya kegiatan ekspor dan impor akan membawa perubahan dalam sektor industri dan sektor perdagangan. Sektor pertanian juga akan berubah melalui pembangunan di bidang sarana dan prasarana, seperti penambahan ruasa jalan.

Pertumbuhan ekonomi (Economic Growth) adalah perkembangan kegiatan dalam perekonomian yang menyebabkan barang dan jasa yang diproduksikan dalam masyarakat bertambah dan kemakmuran masyarakat meningkat. Masalah pertumbuhan ekonomi dapat dipandang sebagai masalah makro ekonomi dalam jangka panjang. Perkembangan kemampuan memproduksi barang dan jasa sebagai akibat pertambahan faktor-faktor produksi pada umumnya tidak selalu diikuti oleh pertambahan produksi barang dan jasa yang sama besarnya. 
Pertambahan potensi memproduksi seringkali lebih besar dari pertambahan produksi yang sebenarnya. Dengan demikian perkembangan ekonomi adalah lebih lambat dari potensinya. (Sukirno, 1994;10).

Pertumbuhan ekonomi dapat diartikan juga sebagai proses kenaikan kapasitas produksi suatu perekonomian yang diwujudkan dalam bentuk kenaikan pendapatan nasional. Perekonomian dikatakan mengalami pertumbuhan apabila jumlah balas jasa riil terhadap penggunaan faktor-faktor produksi pada tahun tertentu lebih besar daripada tahun sebelumnya. Berkelanjutan pertumbuhan ekonomi harus mengarah standar hidup yang lebih tinggi nyata dan kerja meningkat.

Inflasi adalah sebuah keadaan perekonomian yang menunjukan adanya kecenderungan kenaikan tingkat harga secara umum (price level) dan bersifat secara terus-menerus. Hal ini disebabkan karena tidak seimbangnya arus barang dan arus uang yang di sebabkan oleh berbagai faktor. Inflasi juga merupakan salah satu indikator penting dalam menganalisis perekonomian selain pertumbuhan ekonomi, pengangguran, kemiskinan, dan ekspor-inpor. Inflasi merupakan masalah yang sangat besar dalam perekonomian setiap negara dan merupakan suatu fenomena moneter yang selalu meresahkan negara karena kebijakan yang di ambil untuk mengatasi inflasi sering menjadi pisau permata dua yang akan berdampak pada tingkat pertumbuhan ekonomi secara agregat. Diantaranya keseimbangan eksternal dan tingkat bunga. Terjadinya guncangan dalam negri akan menimbulkan fluktuasi harga di pasar domestik yang berakhir dengan peningkatan inflasi pada perekonomian.

\section{METODE}

Jenis data yang digunakan dalam penelitian ini adalah Data Sekunder. Data sekunder yang dipakai adalah data time series (runtut waktu) dari tahun 2001-2015. Sumber data dari BPS Kota Jambi. Dalam penelitian ini menggunakan metode kuantitatif dan kualitatif Untuk pengaruh inflasi terhadap pertumbuhan ekonomi digunakan model analisis Regresi Sederhana. Adapun formulasi matematis dari model analisis dimaksud adalah: $P E=f_{o}+f_{1} \operatorname{Inf}+u_{1}$

Dimana: PE = Pertumbuhan Ekonomi; Inf = Inflasi; $\mathrm{U}_{1}=$ error term; $\mathrm{f}_{0}$ dan $\mathrm{f}_{1}=$ Koefisien regresi

Untuk menguji keberartian koefisien regresi maka digunakan $t$ test :

$$
t_{\text {hitung }}=\frac{\beta_{i}}{\sqrt{S^{2} \beta_{i}}}
$$

dimana : $\beta_{\mathrm{i}}=$ koefisien regresi ke $\mathrm{i} ; \mathrm{S}^{2}=$ Varians; dengan pembanding $: \mathrm{t}_{\text {tabel }}=\mathrm{t}$ $(0,001$ s.d $0,25, \mathrm{n}-\mathrm{k}-1)$ maka rumusan pengujian hipotesis adalah sebagai berikut :

$\mathrm{H}_{\mathrm{o}}: \beta_{2}=0$ : Inflasi tidak berpengaruh terhadap pertmbuhan ekonomi di Kota Jambi

$\mathrm{H}_{1}: \beta_{2} \neq 0$ : Inflasi berpengaruh terhadap pertmbuhan ekonomi di Kota Jambi

Alat analisis yang kedua digunakan untuk menghitung besaran nilai hubungan (korelasi) antara inflasi dan pertumbuhan ekonomi selama periode 2006-2015, digunakan alat uji korelasi sederhana Pearson (Product Moment Coefficient of Correlation) dengan formulasi sebagaimana diungkapkan oleh Siagian dan Sugiarto (2000) dengan formulasi sebagai berikut : 


$$
r_{i}=\frac{n \sum x_{i} y-\sum x_{i} \sum y}{\sqrt{\left(n \sum x_{i}^{2}-\left(\sum x_{i}\right)^{2}\right)\left(n \sum y^{2}-\left(\sum y\right)^{2}\right)}}
$$

Dimana $: r_{i}=$ nilai korelasi antara $x_{i}$ dengan $y ; n=$ jumlah periode; $x_{i}=$ inflasi ke $\mathrm{i} ; \mathrm{y}=$ pertumbuhan ekonomi

Besarnya koefisien korelasi (r) antara dua buah variabel ( $\mathrm{Y}$ dan $\mathrm{X}$ ) adalah nol sampai dengan \pm 1 . Apabila dua buah variabel ( $Y$ dan $X$ ) mempunyai nilai $r$ $=0$ berarti variabel-variabel tersebut tidak ada hubungan. Apabila variabelvariabel itu mempunyai $\mathrm{r}= \pm 1$, maka kedua variabel tersebut mempunyai hubungan yang sempurna. Adapun interpretasi tingkat keeratan hubungan antara variabel $\mathrm{X}$ dengan $\mathrm{Y}$ (variabel bebas dengan variabel terikat), digunakan tabel interpretasi koefisien korelasi dalam Sugiyono (2000:149) sebagai berikut:

\section{Tabel 1}

Pedoman Untuk Memberikan Interpretasi Koefisien Korelasi

\begin{tabular}{cccc}
\hline \multicolumn{2}{c}{ Interval Koefisien } & Tingkat Hubungan \\
\hline 0,00 & - & 0,199 & Sangat rendah \\
0,20 & - & 0,399 & Rendah \\
0,40 & - & 0,599 & Sedang \\
0,60 & - & 0,799 & Kuat \\
0,80 & - & 1,00 & Sangat kuat \\
\hline
\end{tabular}

\section{HASIL}

Inflasi merupakan kecenderungan kenaikan harga secara umum dan terus menerus dalam jangka waktu tertentu. Kenaikan tersebut tidak harus bersamaan atau dengan persentase yang sama akan tetapi kenaikan yang terjadi menunjukkan tren yang terus menerus. Inflasi sendiri dapat diklasifikasikan menrut sifatnya menjadi tiga jenis yaitu : inflasi merayap kenaikan harga yang relatif lambat dalam jangka waktu yang relatif lama dengan persentase di bawah 10 persen.; inflasi menengah dengan kenaikan yang besar dan terkadang mempunyai sifat akselerasi dalam jangkawaktu yang relatif pendek. Dan inflasi tinggi dengan kenaikan harga yang sangat pesat biasanya dengan persentase diatas 30 persen. Klasifikasi tersebut maka kondisi inflasi yang terjadi di Kota Jambi secara rata rata dalam 10 tahun terahir masuk dalam kategori inflasi merayap, dengan persentase kenaikan harga dibawah 10 persen pertahun. Data dibawah ini menunjukkan besarnya tingkat inflasi di Kota Jambi berdasarkan data yang bersumber dari BPS provinsi Jambi.

Tabel 2

Data Inflasi selama Periode 2006-2015

\begin{tabular}{cc}
\hline TAHUN & INFLASI \\
\hline $\mathbf{2 0 0 6}$ & $10.46 \%$ \\
$\mathbf{2 0 0 7}$ & $6.40 \%$ \\
$\mathbf{2 0 0 8}$ & $10.31 \%$ \\
$\mathbf{2 0 0 9}$ & $4.90 \%$ \\
$\mathbf{2 0 1 0}$ & $5.13 \%$
\end{tabular}




\begin{tabular}{rr}
$\mathbf{2 0 1 1}$ & $5.38 \%$ \\
$\mathbf{2 0 1 2}$ & $4.28 \%$ \\
$\mathbf{2 0 1 3}$ & $6.97 \%$ \\
$\mathbf{2 0 1 4}$ & $6.42 \%$ \\
$\mathbf{2 0 1 5}$ & $6.38 \%$ \\
\hline
\end{tabular}

Sumber: Bank Indonesia, 2006 - 2015

Tabel 2 diatas dapat kita lihat laju inflasi tertinggi di kota jambi terjadi pada tahun 2006 dan terendah terjadi pada tahun 2012 yakni hanya mencapai 4,28 persen. Disini juga kita dapat lihat 2013 sampai dengan 2015 pemerintah jambi bisa mempertahankan inflasi pada presentase 6 yang tentu akan mempengaruhi pertumbuhan ekonomi di Kota Jambi. Artinya dalam hal ini pemerintah Kota Jambi bbekerja sangat baik dalam menjaga salah satu faktor yang menjadi penghambat pertumbuhan ekonomi.

Sedangkan PDRB sendiri diartikan sebagai jumlah keseluruhan nilai tambah barang dan jasa yang dihasilkan dari semua kegiatan perekonomian diseluruh wilayah dalam periode tahun tertentu yang pada umumnya dalam waktu satu tahun. Dalam perhitungannya perhitungan PDRB dapat menggunakan dua harga yaitu PDRB harga berlaku dan PDRB harga konstan, yang dimana PDRB harga berlaku merupakan nilai suatu barang dan jasa yang dihitung menggunakan harga yang berlaku pada tahun tersebut, dan PDRB harga konstan adalah nilai suatu barang dan jasa yang dihitung dengan menggunakan harga pada tahun tertentu yang dijadikan sebagai tahun acuan atau tahun dasar. Sementara untuk menghitung total PDRb dalam satu periode digunakan empat pendekatan diantaranya ; pendekatan produksi, pendekatan pendapatan, pendekatan pengeluaran dan pendekatan alokasi.

\section{Tabel 3}

Laju Pertumbuhan PDRB Periode 2006-2015

\begin{tabular}{cc}
\hline TAHUN & PERTUMBUHAN PDRB \\
\hline $\mathbf{2 0 0 6}$ & 5.93 \\
$\mathbf{2 0 0 7}$ & 7.16 \\
$\mathbf{2 0 0 8}$ & 6.14 \\
$\mathbf{2 0 0 9}$ & 6.47 \\
$\mathbf{2 0 1 0}$ & 6.66 \\
$\mathbf{2 0 1 1}$ & 6.97 \\
$\mathbf{2 0 1 2}$ & 7.05 \\
$\mathbf{2 0 1 3}$ & 7.76 \\
$\mathbf{2 0 1 4}$ & 6.64 \\
$\mathbf{2 0 1 5}$ & 5.56 \\
\hline
\end{tabular}

Sumber: BPS Provinsi Jambi, 2006 - 2015

Tabel 3 diatas menunjukkan laju pertumbuhan ekonomi atau PDRB di Kota Jambi selama kurun waktu 10 tahun. Dimana laju pertumbuhan ekonomi tertinggi terjadi pada tahun 2013 yang mencapai 7,76 persen. Artinya dalam memacu pertumbuhan ini pemerintah cukup berhasil hal ini salah satunya disebabkan membaiknya kinerja pemerintah yang mampu menekan angka inflasi pada level yang rendah. Karena inflasi hanya merupakan salah satu faktor yang 
ikut mempengaruhi pertumbuhan ekonomi sehingga meskipun pada tahun 2014 dan 2015 pemerintah mampu mempertahankan tingkat inflasi pada level 6 persen namun pertumbuhan ekonomi di Kota Jambi mengalami penurunan persentase kenaikannya, yang masing masing tumbuh sebesar 6,64 persen pada tahun 2014 dan 5,54 persen pada tahun 2015 .

\section{Analisis Pengaruh Inflasi dengan pertumbuhan ekonomi di Kota Jambi}

Berdasarkan teori dan logika maka inflasi akan berpengaruh negatif terhadap pertumbuhan ekonomi artinya ketika terjadi kenaikan inflasi maka pertumbuhan ekonomi akan mengalami penurunan demikian juga sebaliknnya. Berdasarkan hasil analisis menunjukkan bahwa laju inflasi berpengaruh negatif terhadap pertumbuhan ekonomi meskipun tidak signifikan. Hasil analisis tersebut menunjukkan bahwa kondisi riel yang terjadi sesuai dengan teori yang ada.

\section{Tabel 4}

Koefisien

\begin{tabular}{|c|c|c|c|c|c|}
\hline \multirow[b]{2}{*}{ Model } & \multicolumn{2}{|c|}{ Unstandardized Coefficients } & \multirow{2}{*}{$\begin{array}{c}\text { Standardized } \\
\text { Coefficients } \\
\text { Beta }\end{array}$} & \multirow[b]{2}{*}{$\mathrm{T}$} & \multirow[b]{2}{*}{ Sig. } \\
\hline & $\mathrm{B}$ & Std. Error & & & \\
\hline $1 \quad$ (Constant) & 7.473 & .679 & & 11.006 & .000 \\
\hline INFLASI & -.126 & .098 & -.415 & -1.291 & .233 \\
\hline
\end{tabular}

Sumber: output SPSS

Hasil analisis juga menunjukkan bahwa variabel (inflasi) memberikan kontribusi terhadap perubahan naik atau turunnya pertumbuhan ekonomi sebesar 0.172. Artinya pengaruh variabel inflasi terhadap pertumbuhan ekonomi sebesar 17,2 persen sedangkan 82,8 persennya dipengaruhi oleh faktor lain dan faktor pengganggu (eror term).

Kondisi tersebut dapat dilihat dari bersanya koefisien determinasi berganda $\left(\mathrm{R}^{2}\right)$ yang digunakan untuk mengukur seberapa jauh kemampuan model dalam menerangkan variasi variabelindependent yang terjadi. Dimana jika nilai $\mathrm{R}^{2}$ kecil maka kemampuan variabel independent dalam menjelaskan variasi variabel dependen semakin terbatas. Demikian juga sebaliknya semakin besar nilai $\mathrm{R}^{2}$ maka kemampuan variabel independent dalam menjelaskan variasi variabel dependen semakin bersar atau tidak terbatas.

\section{Analisis hubungan Inflasi dengan pertumbuhan ekonomi di Kota Jambi}

Untuk melihat hubungan antara inflasi dengan pertumbuhan ekonomi yang terjadi digunakan alat uji korelasi sederhana Pearson (Product Moment Coefficient of Correlation) dengan hasil sebagai berikut.

Tabel 5

Korelasi

\begin{tabular}{|c|c|}
\hline \hline & Pertumbuhan Ekonomi \\
\hline Inflasi &,- 236 \\
\hline \hline
\end{tabular}

Sumber: output SPSS 
Tabel 5 diatas menggambarkan bahwa antara inflasi dengan pertumbuhan ekonomi memiliki hubungan negatif sebesar -,236 . Arah hubungan negatif tersebut menunjukkan bahwa selama periode tahun 2006-2015 jika terjadi kenaikan inflasi cenderung akan mengurangi tingkat pertumbuhan ekonomi di Kota Jambi. Demikian juga sebaliknya jika terjadi penurunan inflasi akan menambah peningkatan pertumbuhan ekonomi. Meskipun hubungan yang terjadi dalam kategori sangat lemah akan tetapi peran inflasi dalam mempengaruhi pertumbuhan ekonomi juga cukup besar. Karena dengan tingginya inflasi yang terjadi akan menghambat dalam pembangunan ekonomi dan aktifitas perekonomian pada masyarakat sehingga memperlambat kegiatan perekonomian dan pada akhirnya menurunkan pertumbuhan ekonomi.

\section{SIMPULAN}

Kesimpulan dalam penelitian ini diantaranya adalah:

1. Kondisi inflasi dan pertumbuhan ekonomi di Kota jambi masih cenderung fluktuasi dan belum stabil.

2. Inflasi berpengaruh negatif terhadap pertumbuhan ekonomi di Kota Jambi meskipun tidak signifikan

3. Inflasi mempunyai korelasi negatif terhadap pertumbuhan ekonomi di Kota Jambi

\section{DAFTAR PUSTAKA}

Amir, A., 2007. Pengaruh inflasi dan pertumbuhan ekonomi terhadap pengangguran di Indonesia. Jurnal Inflasi dan Pengangguran, 1(1), 4-9.

Badan Pusat Statistik, 2016. Data Produk Domestik Regional Bruto Kota Jambi 2006 - 2015, Jambi.

Badan Pusat Statistik, 2016. Data Inflasi Kota Jambi 2006 - 2015, Jambi.

Junaidi, Dr., SE., M.Si. 2015. Buku Ajar Ekonometrika 1. Fakultas Ekonomi dan Bisnis, Universitas Jambi. FEB-UNJA

Lubis, I. F., 2014. Analisis Hubungan Antara Inflasi Dan Pertumbuhan Ekonomi: Kasus Indonesia. Quantitative Economics Journal, 3(01).

Noer Ahmad, Sugito., Drs., S.U., 2011. Statistika Lanjutan. Edisi Pertama. Fakultas Ekonomi. Universitas Jendral Sudirman, Puwokerto.

Soleh, A. 2017. Masalah Ketenagakerjaan dan Pengangguran di Indonesia. Cano Ekonomos, 6(2), 83-92.

Soleh, A. 2013. Analisis Struktur Ekonomi dan Ketimpangan Antar Sektor di Kabupaten Tebo Periode 2001-2010. Jurnal Development, 1(2), 30-46.

Soleh, A. 2016. Analisis Pertumbuhan Ekonomi Indonesia. Jurnal Development, 4(2), 18-26. 